Gut, 1978, 19, 419-424

\title{
Effect of ulcer healing on the prognosis of chronic gastric ulcer
}

\author{
Four-year follow-up
}

\author{
D. W. PIPER ${ }^{1}$, JANE SHINNERS, MARGARET GREIG, JOAN THOMAS, AND \\ SHEILA L. WALLER
}

From the Department of Medicine, University of Sydney, at the Royal North Shore Hospital, Sydney, Australia

SUMMARY Eighty three patients were followed-up for four years after an admission to hospital with a chronic gastric ulcer proven by radiology (index ulcer). The index ulcer healed completely in 50 patients, but was unhealed at the time of discharge in the other 33. Significantly fewer patients whose index ulcer was healed compared with those whose ulcer was unhealed at discharge had had a recurrence by one $(P<0.05)$, two, three and four years' $(P<0.01)$ follow-up. Moreover, the rate of recurrence was significantly greater for those patients with unhealed, compared with those with a healed index ulcer $(\mathrm{P}<0.05)$ and by the end of the four-year period $61 \%$ of patients with unhealed, compared with $26 \%$ of those with healed index ulcers had had a recurrence. Patients over the age of 60 years with unhealed index ulcers had a significantly poorer prognosis than those of similar age whose index ulcer was healed at discharge $(P<0.025)$. The sex of the ulcer patient did not significantly influence ulcer recurrence. Large ulcers $\left(>57 \mathrm{~mm}^{2}\right)$ were less often healed on initial discharge and were more frequently associated with recurrence at one $(P<0.05)$, two $(P<0.025)$, three and four years $(P<0.01)$ than smaller ulcers $\left(₹ 57 \mathrm{~mm}^{2}\right)$. Heavy intake of analgesics adversely influenced the course of patients whose ulcer was unhealed $(P<0.05)$, but did not alter the recurrence rate in those whose ulcer was healed. Ulcer recurrence was not influenced by smoking habits or by alcohol consumption.

Hospital admission has been shown to have a beneficial effect on the rate of healing of chronic gastric ulcers (Doll and Pygott, 1952; Herrmann and Piper, 1973), but the value of short-term healing on the long-term prognosis has been little investigated. We have recently demonstrated that up to two years after an admission to hospital for chronic gastric ulcer, patients whose ulcer had been healed at the time of discharge did better, having fewer recurrences and admissions to hospital than those whose ulcer was unhealed when they left hospital (Piper et al., 1975). The present study reports the comparative outcome for these groups during the four

\footnotetext{
${ }^{1}$ Address for reprints: Professor D. W. Piper, Department of Medicine, Royal North Shore Hospital, St. Leonards, NSW 2065, Australia.

Received for publication 16 January 1978
}

years after initial discharge.

\section{Methods}

The patients comprised 83 of the 96 subjects (105 patient admissions) whose short-term follow-up after discharge from the Royal North Shore Hospital has been previously reported (Piper et al., 1975). Of the remaining 13 patients, 11 had died from causes unrelated to their gastric ulcer and two were lost to the study. All had been admitted between 1969 and 1972 with radiological evidence of a chronic gastric ulcer (index admission) and had spent more than seven days in hospital during this admission; the latter time limit excluded patients admitted for diagnostic investigations rather than treatment. None had radiological evidence of duodenal ulceration or scarring, an ulcer in a hiatus hernia, or had had previous gastric surgery. 
FOLLOW-UP

The patients were contacted by post in 1973-74 and again in 1976. Each was sent a questionnaire and asked to record any recurrence of ulcer symptoms which necessitated outpatient treatment or investigation, any admission to hospital for symptoms or complications of the gastric ulcer or for gastric surgery, whether they had had ulcer pain in the month before completing the questionnaire, and their current habits regarding analgesics, smoking, and alcohol. Patients who complained of abdominal pain in the month previous to answering the questionnaire were asked to attend for a barium meal examination. For the purpose of the study, a recurrence was defined as an episode of ulcer symptoms with radiological or endoscopic confirmation of a chronic gastric ulcer, bleeding or perforation of an ulcer, the development of obstructive symptoms, or admission for gastric surgery. The number of patients whose index ulcer was either healed or unhealed on discharge and who suffered one or more recurrences during the first four year follow-up was recorded, but only the first recurrence for each patient has been included in the calculations. The cumulative percentages of patients with healed or unhealed index ulcers who had a recurrence by six months, one, two, three, and four years of follow-up were calculated.

\section{MEASUREMENT OF ULCER SIZE}

Ulcer size was measured at admission and on discharge for the index admission, using a modification of the method devised by Doll and Pygott (1952).

Healing was considered complete if on air-contrast radiology the crater was no longer visible or was less than $1 \mathrm{~mm}^{2}$. Ulcers which were less than $3 \mathrm{~mm}^{2}$ at discharge and were no longer visible after three weeks' outpatient treatment with carbenoxolone sodium were also included in the healed group. The initial index ulcer craters were divided into those with an area equal to or less than $57 \mathrm{~mm}^{2}$ (small) and those with an area of more than $57 \mathrm{~mm}^{2}$ (large), $57 \mathrm{~mm}^{2}$ being the medium size of the ulcer craters included in this study.

\section{STATISTICAL ANALYSIS}

The effects of healing and non-healing, age, sex, initial size of the index ulcer, analgesic intake, smoking, and alcohol consumption on the cumulative percentage of patients with a recurrence were compared between and within the two groups using the chi-square test. The rate of cumulative recurrence for healed and non-healed index ulcers was compared using the Kolmogorov-Smirnov two-sample test (Siegel, 1956).

\section{Results}

The patients studied were 50 (18 men and 32 women) who were discharged with a healed, and 33 (16 men and 17 women) who left hospital with an unhealed index ulcer. Twenty four with a healed and 17 with an unhealed ulcer were aged 60 years or more; the remainder (26 with healed and 16 with unhealed ulcers) were under 60 years of age.

\section{EFFECT OF ULCER HEALING ON RECURRENCE}

Fewer patients who left hospital with their index ulcer healed had a recurrence compared with those whose index ulcer was unhealed at the time of discharge by one $(P<0.05)$, two, three, and four years' follow-up $(\mathbf{P}<0.01)$ (Table 1). Moreover, the rate of recurrence differed significantly for the two groups $(P<0.05)$; by the end of the four-year follow-up, $61 \%$ of patients whose index ulcer failed to heal by discharge had had a recurrence, compared with only $26 \%$ of those whose index ulcer healed (Figure).

\section{EFFECT OF AGE ON RECURRENCE}

It is seen from Table 1 that (1) age did not influence the percentage of patients who had a recurrence in either the healed or unhealed ulcer group; (2) patients aged 60 years or more with an index ulcer healed on discharge less commonly had had a recurrence by two, three, and four years than patients of a similar age whose index ulcers were unhealed at discharge ( $P<0.025)$. On the other hand, the proportion of patients under 60 years of age who had a recurrence was similar, whether or not their index ulcer was healed on discharge from hospital $(P>0.05)$.

\section{EFFECT OF SEX ON RECURRENCE}

Both men and women with healed index ulcers had significantly fewer recurrences than those of the same sex with unhealed index ulcers at two, three, and four years' follow-up $(P<0.05)$. Sex did not influence the number of recurrences within the healed ulcer group (Table 1).

\section{EFFECT OF INITIAL ULCER SIZE ON} RECURRENCE

The initial size of the gastric ulcer was measured for 66 of the 83 subjects; in the other 17 patients, the initial barium meal was not available for assessment. The ulcer crater was small in 33 and large in 33 patients. In this group there were 41 patients with a healed ulcer and 25 with an unhealed index ulcer. Analysis of the data (Table 2) shows (1) there were more patients with initial large ulcers in the unhealed compared with the healed index ulcer 
Effect of ulcer healing on the prognosis of chronic gastric ulcer

Table 1 Effect of ulcer healing, age, and sex on ulcer recurrence

\begin{tabular}{|c|c|c|c|c|c|c|c|c|}
\hline \multirow{2}{*}{$\begin{array}{l}\text { Group and } \\
\text { whole series }\end{array}$} & \multirow[t]{2}{*}{ Index ulcer } & \multirow{2}{*}{$\begin{array}{l}\text { No. of } \\
\text { patients }\end{array}$} & \multicolumn{5}{|c|}{ Cumulative no. of patients with recurrence by } & \multirow{2}{*}{$\begin{array}{l}\% \text { Recur- } \\
\text {-rence at } \\
\text { 4.vr (\%) }\end{array}$} \\
\hline & & & $0.5 y r$ & $1 \mathrm{yr}$ & $2 y r$ & $3 y r$ & $4 y r$ & \\
\hline & $\begin{array}{l}\mathbf{H} \\
\mathbf{U}\end{array}$ & $\begin{array}{l}50 \\
33\end{array}$ & $\begin{array}{l}2 \\
4 \\
>0.10\end{array}$ & $\begin{aligned} & 5 \\
& 9 \\
&< 0.05\end{aligned}$ & $\begin{array}{c}8 \\
15 \\
<0.01\end{array}$ & $\begin{aligned} & 10 \\
& 17 \\
< & 0.01\end{aligned}$ & $\begin{array}{l}13 \\
20 \\
<0.01\end{array}$ & $\begin{array}{l}26 \\
61\end{array}$ \\
\hline $\begin{array}{c}\text { Age (yr) } \\
>60 \\
<60\end{array}$ & $\mathbf{H}$ & $\begin{array}{l}24 \\
26\end{array}$ & $\begin{array}{l}2 \\
0\end{array}$ & $\begin{array}{l}3 \\
2\end{array}$ & $\begin{array}{l}5 \\
3\end{array}$ & $\begin{array}{l}5 \\
5\end{array}$ & $\begin{array}{l}6 \\
7\end{array}$ & $\begin{array}{l}25 \\
27\end{array}$ \\
\hline $\begin{array}{l}>60 \\
<60\end{array}$ & $\begin{array}{l}\mathbf{P} \\
\mathbf{U} \\
\mathbf{P}\end{array}$ & $\begin{array}{l}17 \\
16\end{array}$ & $\begin{array}{l}\overline{2} \\
2 \\
>0.90\end{array}$ & $\begin{array}{c}>0.50 \\
6 \\
3 \\
>0.25\end{array}$ & $\begin{array}{c}>0.30 \\
10 \\
5 \\
>0.10\end{array}$ & $\begin{array}{c}>0.75 \\
10 \\
7 \\
>0.25\end{array}$ & $\begin{array}{c}>0.75 \\
11 \\
9 \\
>0.50\end{array}$ & $\begin{array}{l}65 \\
56\end{array}$ \\
\hline$>60$ & $\begin{array}{l}\mathbf{H} \\
\mathbf{U} \\
\mathbf{P}\end{array}$ & $\begin{array}{l}24 \\
17\end{array}$ & $\begin{array}{l}2 \\
2 \\
>0.75\end{array}$ & $\begin{array}{c}3 \\
6 \\
0.05<\end{array}$ & $\begin{array}{l}5 \\
10 \\
<\quad 0.025\end{array}$ & $\begin{array}{l}5 \\
10 \\
<\quad 0.025\end{array}$ & $\begin{array}{c}6 \\
11 \\
<0.025\end{array}$ & $\begin{array}{l}25 \\
65\end{array}$ \\
\hline$<60$ & $\begin{array}{l}\mathbf{H} \\
\mathbf{U} \\
\mathbf{P}\end{array}$ & $\begin{array}{l}26 \\
16\end{array}$ & $\begin{array}{l}0 \\
2 \\
-\end{array}$ & $\begin{aligned} & 2 \\
& 3 \\
&> 0.25\end{aligned}$ & $\begin{aligned} & 3 \\
& 5 \\
> & 0 \cdot 10\end{aligned}$ & $\begin{aligned} & 5 \\
& 7 \\
> & 0.05\end{aligned}$ & $\begin{aligned} & 7 \\
& 9 \\
> & 0.05\end{aligned}$ & $\begin{array}{l}27 \\
56\end{array}$ \\
\hline Sex & & & & & & & & \\
\hline $\begin{array}{l}\text { Men } \\
\text { Women }\end{array}$ & $\begin{array}{l}\mathbf{H} \\
\mathbf{P}\end{array}$ & $\begin{array}{l}18 \\
32\end{array}$ & $\begin{array}{l}0 \\
2 \\
-\end{array}$ & $\begin{array}{c}1 \\
4 \\
>0 \cdot 30\end{array}$ & $\begin{aligned} & 2 \\
& 6 \\
> & 0 \cdot 10\end{aligned}$ & $\begin{array}{ll} & 3 \\
& 7 \\
> & 0.50\end{array}$ & $\begin{array}{c}3 \\
10 \\
>0.25\end{array}$ & $\begin{array}{l}17 \\
31\end{array}$ \\
\hline $\begin{array}{l}\text { Men } \\
\text { Women }\end{array}$ & $\begin{array}{l}\mathbf{U} \\
\mathbf{P}\end{array}$ & $\begin{array}{l}16 \\
17\end{array}$ & $\begin{aligned} & 3 \\
& 1 \\
&>0.20\end{aligned}$ & $\begin{aligned} & 4 \\
& 5 \\
&> 0.75\end{aligned}$ & $\begin{aligned} & 7 \\
& 8 \\
&> 0.75\end{aligned}$ & $\begin{aligned} & 8 \\
& 9 \\
> & 0.75\end{aligned}$ & $\begin{array}{c}9 \\
11 \\
>0.50\end{array}$ & $\begin{array}{l}56 \\
65\end{array}$ \\
\hline Men & $\begin{array}{l}\mathbf{H} \\
\mathbf{U} \\
\mathbf{P}\end{array}$ & $\begin{array}{l}18 \\
16\end{array}$ & $\begin{array}{l}0 \\
3 \\
-\end{array}$ & $\begin{aligned} & 1 \\
& 4 \\
> & 0.10\end{aligned}$ & 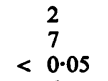 & 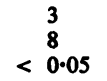 & $\begin{array}{l}3 \\
9 \\
< \\
0.025\end{array}$ & $\begin{array}{l}17 \\
56\end{array}$ \\
\hline Women & $\begin{array}{l}\mathbf{H} \\
\mathbf{U} \\
\mathbf{P}\end{array}$ & $\begin{array}{l}32 \\
17\end{array}$ & $\begin{array}{c}2 \\
1 \\
>0.90\end{array}$ & $\begin{array}{l}4 \\
5 \\
>0.10\end{array}$ & $\begin{aligned} & 6 \\
& 8 \\
< & 0.05\end{aligned}$ & $\begin{aligned} & 7 \\
& 9 \\
< & 0.05\end{aligned}$ & $\begin{array}{c}10 \\
11 \\
<0.05\end{array}$ & $\begin{array}{l}31 \\
65\end{array}$ \\
\hline
\end{tabular}

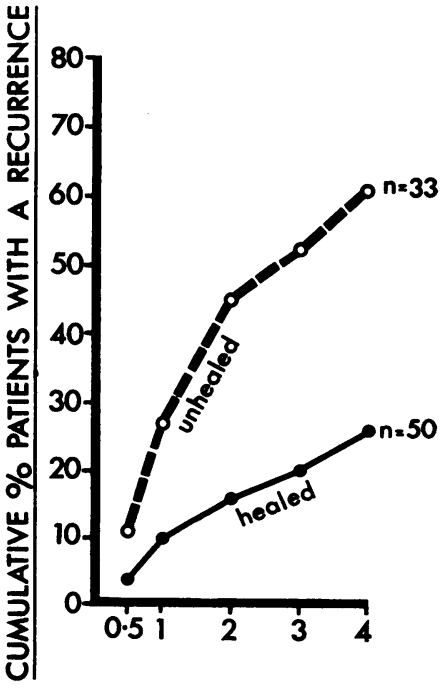

YEARS

Figure Cumulative recurrence rate over four years in patients with healed and unhealed ulcers

group ( $P$ < 0.025); (2) as for the larger group from which they were derived, significantly more patients with an unhealed index ulcer had a recurrence than those with healed index ulcers at six months
$(P<0.05)$, one year $(P<0.025)$, and two, three, and four years $(P<0.01)$; (3) more patients with large ulcers had had a recurrence than those with small index ulcers by one $(P<0.05)$, two $(P<0.025)$ three and four years after discharge for the index ulcer $(P<0.01)$; (4) in the healed ulcer group, a greater percentage of patients with large ulcers had a recurrence than those with small ulcers only at two and three years' follow up $(P<0.05)$. The size of the ulcer appeared to have no effect in the unhealed group $(P>0 \cdot 10)$; (5) in the small ulcer group, a beneficial effect conferred by healing on discharge was apparent at two years and four years $(P<0.05)$ but in the large ulcer group, no benefit was conferred by healing at discharge $(0.05<\mathrm{P}<0.10)$.

EFFECT OF ANALGESICS, SMOKING, AND ALCOHOL

Analgesics (Table 3)

The numbers of those who took no analgesics and daily or less than daily analgesics was similar in those with healed and unhealed ulcers $(P=0.3$ and 0.9 respectively).

In those who left hospital with their ulcer healed, analgesic intake did not influence the recurrence rate but daily analgesic intake adversely influenced the course of those who left with their ulcer unhealed $(P<0.05)$. Less than daily analgesic intake exerted no adverse effect on either group. 
Table 2 Effect of size of index ulcer on ulcer recurrence

\begin{tabular}{|c|c|c|c|c|c|c|c|c|}
\hline \multirow[t]{2}{*}{ Group } & \multirow[t]{2}{*}{ Index ulcer } & \multirow{2}{*}{$\begin{array}{l}\text { No. of } \\
\text { patients }\end{array}$} & \multicolumn{5}{|c|}{ Cumulative no. of patients with recurrence by } & \multirow{2}{*}{$\begin{array}{l}\% \text { Recur- } \\
\text { rence at } 4 \\
y r(\%)\end{array}$} \\
\hline & & & $0.5 \mathrm{yr}$ & $1 y r$ & $2 y r$ & $3 y r$ & $4 y r$ & \\
\hline \multirow{2}{*}{$\begin{array}{l}\text { Whole } \\
\text { Subgroup }\end{array}$} & $\mathbf{H}$ & 41 & 1 & 4 & 7 & 9 & 10 & \multirow{2}{*}{$\begin{array}{l}24 \\
64\end{array}$} \\
\hline & $\begin{array}{l}\mathbf{U} \\
\mathbf{P}\end{array}$ & 25 & $\begin{array}{c}4 \\
<0.05\end{array}$ & $\begin{array}{c}8 \\
<0.025\end{array}$ & $\begin{aligned} & 12 \\
< & 0.01\end{aligned}$ & $\begin{array}{l}14 \\
<0.01\end{array}$ & $\begin{array}{l}16 \\
<\quad 0.01\end{array}$ & \\
\hline \multirow{2}{*}{$\begin{array}{l}\text { Whole } \\
\text { Subgroup }\end{array}$} & $\leqslant 57 \mathrm{~mm}^{2}$ & 33 & 2 & 3 & 5 & 6 & 8 & \multirow{2}{*}{$\begin{array}{l}24 \\
55\end{array}$} \\
\hline & $\begin{array}{l}>57 \mathrm{~mm}^{2} \\
\mathrm{P}\end{array}$ & 33 & $\begin{array}{c}3 \\
>0.50\end{array}$ & $\begin{array}{c}9 \\
<0.05\end{array}$ & $\begin{array}{l}14 \\
<0.025\end{array}$ & $\begin{array}{c}17 \\
<0.01\end{array}$ & $\begin{array}{c}18 \\
<0.01\end{array}$ & \\
\hline \multirow[t]{2}{*}{$\begin{array}{l}\leqslant 57 \mathrm{~mm}^{2} \\
>57 \mathrm{~mm}^{2}\end{array}$} & $\mathbf{H}$ & $\begin{array}{l}25 \\
16\end{array}$ & $\begin{array}{l}0 \\
1\end{array}$ & $\begin{array}{l}1 \\
3\end{array}$ & $\begin{array}{l}2 \\
5\end{array}$ & $\begin{array}{l}3 \\
6\end{array}$ & $\begin{array}{l}4 \\
6\end{array}$ & \multirow[t]{2}{*}{$\begin{array}{l}16 \\
38\end{array}$} \\
\hline & $\mathbf{P}$ & & - & $>0.10$ & $<0.05$ & $<0.05$ & $>0.10$ & \\
\hline \multirow{3}{*}{$\begin{array}{l}\leqslant 57 \mathrm{~mm}^{2} \\
>57 \mathrm{~mm}^{2}\end{array}$} & U & 8 & 2 & 2 & 3 & 3 & 4 & \multirow{3}{*}{$\begin{array}{l}50 \\
71\end{array}$} \\
\hline & & 17 & $\overline{2}$ & $\overline{6}$ & 9 & 11 & 12 & \\
\hline & $\mathbf{P}$ & & $>0.50$ & $>0.25$ & $>0.25$ & $>0 \cdot 10$ & $>0.25$ & \\
\hline \multirow[t]{2}{*}{$\leqslant 57 \mathrm{~mm}^{2}$} & $\begin{array}{l}\mathbf{H} \\
\mathbf{U}\end{array}$ & $\begin{array}{r}25 \\
8\end{array}$ & $\begin{array}{l}0 \\
2\end{array}$ & $\begin{array}{l}1 \\
2\end{array}$ & $\begin{array}{l}2 \\
3\end{array}$ & $\begin{array}{l}3 \\
\mathbf{3}\end{array}$ & $\begin{array}{l}4 \\
4\end{array}$ & \multirow[t]{2}{*}{$\begin{array}{l}16 \\
50\end{array}$} \\
\hline & $\mathbf{P}$ & & - & $0.05<P<0.10$ & $<0.05$ & $0.05<P<0.10$ & $<0.05$ & \\
\hline$>57 \mathrm{~mm}^{2}$ & $\begin{array}{l}\mathbf{H} \\
\mathbf{U} \\
\mathbf{P}\end{array}$ & $\begin{array}{l}16 \\
17\end{array}$ & $\begin{array}{l}1 \\
2 \\
>0.50\end{array}$ & 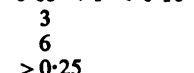 & $\begin{array}{l}5 \\
9 \\
>0 \cdot 10\end{array}$ & $\begin{array}{l}6 \\
11 \\
>0.10\end{array}$ & $\begin{array}{r}6 \\
12 \\
0.05<P<0.10\end{array}$ & $\begin{array}{l}38 \\
71\end{array}$ \\
\hline
\end{tabular}

Table 3 Effect of analgesics on ulcer recurrence

\begin{tabular}{|c|c|c|c|c|}
\hline \multirow[t]{2}{*}{ Status on discharge } & \multirow[t]{2}{*}{ Total no. } & \multicolumn{2}{|c|}{ With recurrence } & \multirow{2}{*}{$\begin{array}{l}\text { Sig. of analgesic } \\
\text { effect (P) }\end{array}$} \\
\hline & & (no.) & $(\%)$ & \\
\hline $\begin{array}{l}\text { Healed (50) } \\
\text { No analgesics } \\
\text { Daily } \\
\text { Less than daily or none } \\
\text { Less than daily } \\
\text { All takers of analgesics } \\
\text { Unhealed (33) } \\
\text { No analgesics } \\
\text { Daily } \\
\text { Less than daily or none } \\
\text { Less than daily } \\
\text { All analgesic takers }\end{array}$ & $\begin{array}{r}50 \\
30 \\
12 \\
38 \\
8 \\
20 \\
33 \\
33 \\
16 \\
12 \\
21 \\
5 \\
17\end{array}$ & $\begin{array}{r}13 \\
10 \\
2 \\
11 \\
1 \\
3 \\
20 \\
9 \\
10 \\
10 \\
1 \\
11\end{array}$ & $\begin{array}{l}26 \\
33 \\
17 \\
29 \\
12 \\
15 \\
61 \\
56 \\
83^{*} \\
48 \\
20 \\
65\end{array}$ & \} $\mathbf{N S}+$ \\
\hline
\end{tabular}

${ }^{*} \mathrm{P}<0.05 \quad \dagger \mathrm{NS}$ : not significant.

Smoking (Table 4)

Approximately half of both those with a healed and unhealed index ulcer were smokers; heavy smokers were more common in those who left with their ulcer healed. Smoking did not influence number of recurrences, whether or not the index ulcer healed.

\section{Alcohol intake (Table 5)}

Alcohol intake was similar in those who were discharged with a healed or unhealed ulcer and alcohol ingestion did not significantly alter the course of either group.

\section{EFFECT OF INITIAL HEALING RATE AND TIME SPENT IN HOSPITAL ON RECURRENCE RATE}

These results are shown in Table 6. Statistical analysis shows that (1) in the healed index ulcer group, there was no relationship between the time spent in hospital (which is an index of the time required for healing) and recurrence rate $(0.05<$
$P<0 \cdot 1)$; in this group, however, when analysed in terms of those healed in less or more than three weeks, 29 were healed in less than three weeks with four recurrences, whereas 21 required more than three weeks with nine recurrences. This difference is significant $(0.01<P<0.025)$; (2) in the unhealed group, there was no correlation with recurrence rate and the time spent in hospital $(0.4<\mathrm{P}<0.5)$.

\section{Discussion}

The first therapeutic measure demonstrated to accelerate gastric ulcer healing was admission to hospital (Doll and Pygott, 1952). More recently, other therapeutic measures have been shown to produce a comparable healing rate; these have included carbenoxolone sodium (Doll et al., 1962; Pinder et al., 1976), tripotassium dicitrato bismuthate (Boyes et al., 1974), and cimetidine (Ciclitira et al., 1977; Multicentre trial, 1977; Hunt et al., 1977; Frost et al., 1977; Landecker et al., personal com- 
Table 4 Effect of smoking on ulcer recurrence

\begin{tabular}{|c|c|c|c|}
\hline Index ulcer & Recurrence & No recurrence & $\mathbf{P}$ \\
\hline \multicolumn{4}{|l|}{ Healed (50) } \\
\hline Non-smokers (25) & 8 & 17 & \\
\hline Smokers (25) & 5 & 20 & \\
\hline Heavy smokers (21) & 5 & 16 & \\
\hline Light smokers (4) & 0 & 4 & \\
\hline \multicolumn{4}{|l|}{ Unhealed (33) } \\
\hline Non-smokers (17) & 8 & 9 & \\
\hline Smokers (16) & 12 & 4 & \\
\hline Heavy smokers (9) & 7 & 2 & \\
\hline Light smokers (7) & 5 & 2 & \\
\hline
\end{tabular}

Heavy smokers: > 20 cigarettes/day. Light smokers : < 20 cigarettes/day. *NC: not calculated.

Table 5 Effect of alcohol on ulcer recurrence

\begin{tabular}{|c|c|c|c|c|c|}
\hline Index ulcer & Alcohol intake & & Recurrence & Non-recurrence & $\mathbf{P}$ \\
\hline $\begin{array}{l}\text { Healed (50) } \\
\text { Unhealed (33) }\end{array}$ & $\begin{array}{l}\text { No alcohol } \\
\text { Alcohol + } \\
\text { Daily alcohol } \\
\text { Social alcohol } \\
\text { No alcohol } \\
\text { Alcohol } \\
\text { Daily alcohol } \\
\text { Social alcohol }\end{array}$ & $\begin{array}{r}(25) \\
(25) \\
(21) \\
(4) \\
(12) \\
(21) \\
(9) \\
(3)\end{array}$ & $\begin{array}{r}5 \\
8 \\
3 \\
2 \\
14 \\
6 \\
6 \\
0\end{array}$ & $\begin{array}{r}20 \\
17 \\
18 \\
2 \\
7 \\
6 \\
3 \\
3\end{array}$ & \\
\hline
\end{tabular}

*NC: not calculated.

Table 6 Effect of time in hospital and initial healing rate on recurrence rate

\begin{tabular}{lcccc}
\hline & \multicolumn{2}{c}{ Time of discharge from hospital (weeks) } & & \\
\cline { 2 - 5 } & $<3$ & $>3$ & $3-6$ & $>6$ \\
\hline Healed (50) & 29 & 21 & 5 & 2 \\
No. with recurrence & 4 & 9 & 8 & 9 \\
$\quad$ by 4 yr (13) & 16 & 17 & 6 & 6 \\
Unhealed (33) & 8 & 12 & & \\
No. with recurrence & & & & \\
$\quad$ by 4 yr (20) & & & & \\
\hline
\end{tabular}

munication). The beneficial effect induced by hospital admission observed by Doll and Pygott (1952) was less obvious after three months after discharge and the value of short-term healing on the long-term prognosis of gastric ulcer has been questioned (Doll, 1964, Langman, 1976). Another problem related to complete healing by hospital admission was the expense and social inconvenience involved and uncertainty as to whether the symptomatic relief and healing that was produced altered the natural cycle of remission and exacerbation that characterises ulcer disease. The present study, while emphasising the high recurrence rate even under optimal conditions, does show that complete healing confers a beneficial effect that lasts for at least four years and appears to increase with time of follow-up (Figure). It also shows that, whereas other factors such as ulcer size, age, and analgesics to a greater or lesser extent influence the recurrence rate, the dominant influence in all groups is whether the ulcer was completely healed; this suggests that the cost and social inconvenience associated with ulcer healing is justified. This could be considered of particular relevance in the older patient in whom complications are associated with considerable mortality.

The effect of analgesics on the course of gastric ulcer is clarified in this study and again demonstrates the dominant effect of ulcer healing, because, in the healed group, analgesics exert no adverse effect even with heavy analgesic intake, though an adverse effect due to analgesics is present if the ulcer is not healed and the analgesic intake is heavy. The relatively unimportant role of analgesics is further demonstrated by the fact that there is no difference due to sex and it is found that women take analgesics more commonly than men (Piper et al., 1977).

The findings in this report are now divergent from those in a few other studies that have looked at the problem. The Veterans Administration study reported a $42 \%$ recurrence over two years for men whose ulcers had healed by 12 weeks (including a 
three week initial hospital admission) and a $62 \%$ recurrence rate for those whose ulcers failed to heal in this time (Hanscom and Buchman, 1971). The lack of a significant effect on the long-term prognosis of initial healing reported initially (Piper et al., 1975 ) is confirmed in the present study.

The present study was retrospective and the patients included in the healed and unhealed groups were self-selected and not allocated by randomisation. It is unlikely, however, that these factors or patient compliance could account for the differences observed. The compliant patient who acquiesces in the request to stay in hospital until the ulcer is healed could reasonably be expected to report minor episodes of ulcer dyspepsia with a higher incidence of ulcer recurrence and thereby mask the beneficial effect due to complete healing.

Data from several countries show that ulcer disease is an important source of mortality, morbidity, and economic loss (Watkinson, 1960; Avery Jones and Gummer, 1960; Stanford Research Institute, 1977) and several publications showed a good result that can be obtained surgically with minimal mortality (Callum and Talbot, 1973, Duthie and Kwong, 1973, Nielsen et al., 1973). On the basis of the latter information and the data presented in this study, it can be strongly recommended that every ulcer be completely healed. This in particular applies to the elderly patient with a large ulcer, especially if he or she takes analgesics. As has been advised previously, if recurrence is rapid (less than two years) after healing, surgery should be advised (Piper et al., 1975).

We thank the National Health and Medical Research Council, Ramaciotti Foundations and the Australian Tobacco Research Foundation for financial support.

\section{References}

Boyes, B. E., Woolf, I. L., Wilson, R. Y., Cowley, D. J., and Dymock, I. W. (1974). Effective treatment of gastric ulceration with a bismuth preparation (De-Nol) (Abstract). Gut, 15, 833.

Callum, K. G., and Talbot, J. E. (1973). The surgical treatment of peptic ulcer: a 15-year review. British Journal of Surgery, 60, 511-516.

Ciclitira, P. J., Machell, R. J., Farthing, M. J., Dick, A. P., and Hunter, J. (1977). A controlled trial of cimetidine in the treatment of gastric ulcer. In Cimetidine: Proceedings of the Second International Symposium on Histamine $\mathrm{H}_{2}$ Receptor Antagonists, pp. 283-286. Edited by W. L. Burland and M. A. Simkins. Excerpta Medica: Amsterdam and Oxford.

Doll, R. (1964). Medical treatment of gastric ulcer. Scottish Medical Journal, 9, 183-196.

Doll, R., Hill, I. D., Hutton, C., and Underwood, D. J., II. (1962). Clinical trial of a triterpenoid liquorice compound in gastric and duodenal ulcer Lancet, 2, 793-796.

Doll, R., and Pygott, F. (1952). Factors influencing the rate of healing of gastric ulcers-admission to hospital, phenobarbitone and ascorbic acid. Lancet, 1, 171-175.

Duthie, H. L., and Kwong, N. K. (1973). Vagotomy or gastrectomy for gastric ulcer. British Medical Journal, 4, 79-81.

Hanscom, D. H., and Buchman, E. (1971). The Veterans Administration cooperative study on gastric ulcer: the follow-up period. Gastroenterology, 61, 585-591.

Herrmann, R. P., and Piper, D. W. (1973). Factors influencing the healing rate of chronic gastric ulcer. American Journal of Digestive Diseases, 18, 1-6.

Hunt, R. H., Vincent, S. H., Milton-Thompson, G. J., Pounder, R. E., Taylor, R., Misiewicz, J. J., Golding, P. L., and Colin-Jones, D. G. (1977). Cimetidine in the treatment of gastric ulcer. In Cimetidine: Proceedings of the Second International Symposium on Histamine $\mathrm{H}_{2}$-Receptor Antagonists, pp. 293. Edited by W. L. Burland and M. A. Simkins. Excerpta Medica: Amsterdam and Oxford.

Jones, F. Avery, and Gummer, J. W. P. (1960). Clinical Gastroenterology (2nd edition), p. 322. Blackwell Scientific Publications: Oxford.

Landecker, K. D., Hunt, J. H., Gillespie, P., and Piper, D. W. (1977). Cimetidine and gastric ulcer healing. A double blind controlled trial. Personal communication.

Langman, M. J. S. (1976). Carbenoxolone sodium: its role in ulcer healing. Drugs, 11, 241-244.

Multicentre trial (1977). Treatment of gastric ulcer by cimetidine. In Cimetidine: Proceedings of the Second International Symposium on Histamine $\mathrm{H}_{2}$-Receptor Antagonists, pp. 287-292. Edited by W. L. Burland and M. A. Simkins, Excerpta Medica: Amsterdam and Oxford.

Nielsen, J., Amdrup, E., Christiansen, P., Fenger, C., Jensen, H. E., Lindskov, J., and Nielsen, S. A. D. (1973). Gastric ulcer. II. Surgical treatment. Acta Chirurgica Scandinavica, 139, 460-465.

Pinder, R. M., Brogden, R. N., Sawyer, P. R., Speight, T. M., Spencer, R., and Avery, G. S. (1976). Carbenoxolone: a review of its pharmacological properties and therapeutic efficacy in peptic ulcer disease. Drugs, 11, 245-307.

Piper, D. W., Cumberland, V. H., and Fevre, D. I. (1977). Management of chronic peptic ulcer and its complications. Current Therapeutics, March, 1975, 39-50.

Piper, D. W., Greig, M., Coupland, G. A. E., Hobbin, E., and Shinners, J. (1975). Factors relevant to the prognosis of chronic gastric ulcer. Gut, 16, 714-718.

Piper, D. W., Greig, M., Landecker, K. D., Shinners, J., Waller, S, and Canalese, J. (1977). Analgesic intake and chronic gastric ulcer, acute gastro-intestinal haemorrhage, personality traits and social class. Proceedings of Aspirin Symposium, London. Rayleigh Printers; Rochford, Essex, U.K. In Press.

Siegel, S. (1956). Nonparametric Statistics for Behavioral Sciences, pp. 127-136. McGraw Hill: New York, London, and Toronto.

Stanford Research Institute (1977). Cost of ulcer disease in the United States. Prepared for Smith, Kline Corporation, Philadelphia, Pennsylvania. USA.

Swynnerton, B. F., and Tanner, N. C. (1953). Chronic gastric ulcer. A comparison between a gastroscopically controlled series treated medically and a series treated by surgery. British Medical Journal, 2, 841-847.

Watkinson, G. (1960). The incidence of chronic peptic ulcer found at necropsy, A study of 20000 examinations performed in Leeds in 1930-49 and in England and Scotland in 1956. Gut, 1, 14-30. 